\title{
THE BRAZILIAN AMS RADIOCARBON LABORATORY (LAC-UFF) AND THE INTERCOMPARISON OF RESULTS WITH CENA AND UGAMS
}

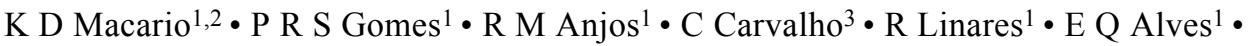 \\ F M Oliveira ${ }^{1}$ M D Castro ${ }^{1,4} \bullet$ I S Chanca $^{1} \bullet \mathrm{M} \mathrm{F} \mathrm{M} \mathrm{Silveira}^{1} \bullet$ L C R Pessenda ${ }^{5}$ L M B Moraes $^{5} \bullet$ \\ T B Campos ${ }^{5} \cdot$ A Cherkinsky $^{6}$
}

\begin{abstract}
After $22 \mathrm{yr}$ of the low-level liquid scintillation counting ${ }^{14} \mathrm{C}$ laboratory at the Center for Nuclear Energy in Agriculture (CENA) at São Paulo University (USP), Piracicaba, Brazil, and several collaborative projects with Brazilian and international researchers from distinct scientific areas, the first ${ }^{14} \mathrm{C}$ accelerator mass spectrometry (AMS) laboratory in Latin America was installed at the Physics Institute of the Universidade Federal Fluminense (UFF), Niterói, Brazil. A 250kV single stage accelerator produced by National Electrostatics Corporation began its operation in 2012. In this work, we compare measurements performed at the AMS Radiocarbon Laboratory at UFF (LAC-UFF) with those performed at CENA and the University of Georgia (UGAMS), Georgia, USA. All the results obtained from distinct inorganic and organic samples were in very good agreement.
\end{abstract}

\section{INTRODUCTION}

Since the early 1970s, the Brazilian Quaternary community has progressively increased its interest in distinct scientific areas such as archaeology, botany, geography, geology, oceanography, etc., in order to reconstruct the paleoenvironment associated with vegetation, sea-level, and climate dynamics during at least the last 50,000 yr. In addition, we are interested in characterizing climatic changes and anthropogenic activity during the Holocene. However, the lack of radiocarbon laboratories with a stable and lasting routine and the high costs of sample measurement at foreign laboratories provoked a "scientific delay" of 1 to 2 decades for Late Quaternary environmental studies. To provide analytical support for Brazilian scientists, a ${ }^{14} \mathrm{C}$ laboratory was installed in 1990 at the Center for Nuclear Energy in Agriculture (CENA), University of São Paulo, São Paulo State, Southeastern region, using a benzene liquid scintillation counting (LSC) system. This system was tested through 2 successful intercomparisons with laboratories in Canada and USA (Pessenda et al. 1991) and with 68 other participants in the international program coordinated by the IAEA (Rozanski 1991; Pessenda et al. 1993).

Multidisciplinary work has been performed in the fields of archaeology, marine biology, and geosciences (Santos et al. 2000, 2001; Gomes et al. 2000, 2004; Lima et al. 2002, 2003, 2004; Barbosa JA et al. 2004; Barbosa M et al. 2004; Macario et al. 2004, 2009; Ferraz et al. 2004; Anjos et al. 2010). Previous studies have addressed the chronology of prehistoric settlements of the centralsouth Brazilian coast (Lima et al. 2002, 2003, 2004; Barbosa M et al. 2004; Macario et al. 2009; Anjos et al. 2010). In this region, there is a high density of shellmounds, intentionally built by prehistoric populations, dated in general between 6 and $2 \mathrm{ka} \mathrm{BP}$. The material culture recovered at these sites includes artifacts made from shells and bones, and charcoal from hearths. In the region of Cabo

\footnotetext{
${ }^{1}$ Instituto de Física, Universidade Federal Fluminense. Av. Gal. Milton Tavares de Souza, S/N, Niterói 24210-346 RJ, Brazil. ${ }^{2}$ Corresponding author. Email: kita@if.uff.br.

${ }^{3}$ Departamento de Ciências da Natureza, Universidade do Estado do Rio de Janeiro. Rua Santa Alexandrina, 288, Rio de Janeiro 20261-232 RJ, Brazil.

${ }^{4}$ Instituto Superior de Tecnologías y Ciencias Aplicadas, InSTEC, Quinta de los Molinos, Ave. Salvador Allende y Luaces, Plaza de la Revolución, Havana, Cuba.

${ }^{5}$ CENA- USP, Avenida Centenário, 303, Piracicaba 13416-000 SP, Brazil.

${ }^{6}$ UGAMS, Center for Applied Isotope Studies, CAIS, University of Georgia, 120 Riverbend Rd., Athens, Georgia 30602, USA.
}

(C) 2013 by the Arizona Board of Regents on behalf of the University of Arizona Proceedings of the 21st International Radiocarbon Conference edited by A J T Jull \& C Hatté RADIOCARBON, Vol 55, Nr 2-3, 2013, p 325-330 


\section{K D Macario}

Frio, Rio de Janeiro State, we have participated in projects in the fields of oceanography and marine ecology, investigating the isotopic signature of waters from coastal upwelling by measuring seaweed samples (Ferraz et al. 2004; Gomes et al. 2004) and sedimentation rates in the offshore by dating foraminifera shells (Macario et al. 2004). In the Amazon region, charcoal from old fires in the rainforest of the central Amazon were studied (Gomes et al. 2000; Santos et al. 2000) as well as the correlation between mercury and carbon fluxes with fires by using samples from sediment cores taken from a remote lake in northern Amazonia at the Pico da Neblina National Park (Santos et al. 2001; Barbosa JA et al. 2004; Gomes et al. 2004).

With the continuous expansion of paleoenvironmental interdisciplinary studies of Pleistocene and Holocene vegetation, climate changes, and sea-level dynamics in distinct Brazilian regions (Angulo et al. 1999; Freitas et al. 2001; Pessenda et al. 2001, 2004a,b, 2005, 2009, 2010, 2012; Sifeddine et al. 2001; Gouveia et al. 2002; Cruz et al. 2006; Ledru et al. 2006; Saia et al. 2008; Rossetti et al. 2010; Buso et al. 2012; Cohen et al. 2012; Guimarães et al. 2012), as well as the significant presence of a new generation of paleoresearchers, the need for additional analyses has increased. Consequently, the installation of another laboratory was very important to the Brazilian Quaternary community. The first Brazilian ${ }^{14} \mathrm{C}$ sample preparation laboratory for the AMS technique was installed in 2009 at the Physics Institute of Universidade Federal Fluminense (Anjos et al. 2013). A singlestage accelerator mass spectrometry (SSAMS) system produced by National Electrostatic Corporation began its operation at the Physics Institute in March 2012, completing the infrastructure of the Radiocarbon Laboratory of UFF (LAC-UFF). The aim of this paper is to present the first results produced at the AMS ${ }^{14} \mathrm{C}$ facility of UFF, in an intercomparison test with the laboratories of CENA and the AMS facility at the University of Georgia's Center for Applied Isotope Studies (CAIS)

\section{MATERIALS AND METHODS}

For the intercomparison of results, 10 different samples collected for the FAPESP (São Paulo Foundation for Research Support) Thematic Project, "Paleoenviromental interdisciplinary studies in the coastal region of Espírito Santo State," were pretreated at CENA and divided into 2 groups. In the first set, 5 samples of different matrices (see Table 1) were physically pretreated to remove impurities such as roots, seeds, etc. Then, organic samples were chemically treated with $\mathrm{HCl} 2-4 \%$ at 60 $80{ }^{\circ} \mathrm{C}$ for $4-5 \mathrm{hr}$, washed with distilled water until $\mathrm{pH} \sim 5$, and dried at $60{ }^{\circ} \mathrm{C}$. The shell sample was physically and chemically $(\mathrm{HCl} 2 \%)$ treated to remove organic compounds and the secondary carbonate, respectively, and dried at $60^{\circ} \mathrm{C}$. Each sample was replicated and measured at CENA, by using the benzene synthesis liquid scintillation counting method (Pessenda and Camargo 1991), and at LAC-UFF by ${ }^{14} \mathrm{C}$ AMS. At LAC-UFF, all samples were converted to carbon dioxide. Organic samples were combusted in quartz tubes at $900{ }^{\circ} \mathrm{C}$ for $3 \mathrm{hr}$ and the shell sample was hydrolyzed in phosphoric acid.

In the second group, 5 pretreated lake sediment samples (see Table 2) were converted to $\mathrm{CO}_{2}$ at CENA and divided into 2 tubes to be sent to both the ${ }^{14} \mathrm{C}$ AMS Laboratory at CAIS, University of Georgia, USA, and to LAC-UFF for graphitization and measurements.

For the third study, IAEA reference materials ( $\mathrm{C} 2, \mathrm{C} 5$, and $\mathrm{C} 6)$ were prepared for quality control. The $\mathrm{C} 5$ wood sample was $\mathrm{ABA}(1.0 \mathrm{M} \mathrm{HCl}$ and $1.0 \mathrm{M} \mathrm{NaOH})$ pretreated at $90{ }^{\circ} \mathrm{C}$ for at least $2 \mathrm{hr}$ each. The C6 sucrose samples, oxalic acid (NBS 4990c), and graphite blanks were directly combusted at $900{ }^{\circ} \mathrm{C}$. For calcite blanks and $\mathrm{C} 2$ carbonate reference material, samples were reacted with $0.5 \mathrm{M} \mathrm{HCl}\left(\right.$ at $\left.90^{\circ} \mathrm{C}\right)$. After carbon dioxide conversion, all gas samples were cryogenically purified in a stainless steel sample preparation line and kept under vacuum at $1.0 \mathrm{mTorr}$. Graphitization was 
performed using $30-35 \mathrm{mg}$ zinc and $10-15 \mathrm{mg}$ titanium hydrate, with $3-5 \mathrm{mg}$ iron catalyst into Pyrex ${ }^{\circledR}$ tubes and reacted at $520^{\circ} \mathrm{C}$ for $7 \mathrm{hr}$ (Xu et al. 2007). Graphite targets were measured in the AMS (NEC 250kV SSAMS) compact system using the $1^{+}$charge state. Typical currents were $50 \mu \mathrm{A}$ ${ }^{12} \mathrm{C}^{-1}$ measured at the low-energy Faraday cup. The isotopic fractionation is corrected by measuring the ${ }^{13} \mathrm{C}$ on-line in the accelerator. Graphite and calcite blanks yielded average ${ }^{14} \mathrm{C} /{ }^{13} \mathrm{C}$ ratios of $1.3 \times$ $10^{-12}$ and $1.1 \times 10^{-12}$, respectively. Average machine background $\left({ }^{14} \mathrm{C} /{ }^{13} \mathrm{C}\right)$ was $10^{-13}$ and average precision was $0.8 \%$. Results are expressed as radiocarbon ages $\left({ }^{14} \mathrm{C}\right.$ yr $\left.\mathrm{BP}\right)$ normalized to a $\delta^{13} \mathrm{C}$ of $-25 \%$ PDB, denoted as VPDB, or percentage of modern carbon (pMC) (Stuiver and Polach 1977).

\section{RESULTS AND DISCUSSION}

Table 1 shows the results for the first set of samples measured at CENA and LAC-UFF. Considering the error of $\pm 2 \sigma$ for all analyzed material, one can observe the very good agreement of results obtained for all samples.

Table 1 Results of the first set of samples.

\begin{tabular}{lclcl}
\hline $\begin{array}{l}\text { Lab code } \\
\text { CEN- }\end{array}$ & $\begin{array}{c}\text { CENA age } \\
\left({ }^{14} \mathrm{C} \text { yr BP }\right)\end{array}$ & Material & $\begin{array}{c}\text { LAC-UFF age } \\
\left({ }^{14} \mathrm{C} \text { yr BP }\right)\end{array}$ & $\begin{array}{l}\text { Lab code } \\
\text { LACUFF- }\end{array}$ \\
\hline 1126 & $6240 \pm 90$ & Shells & $6145 \pm 32$ & 12001 \\
1142 & $24,200 \pm 400$ & Organic soil & $23,625 \pm 233$ & 12002 \\
1150 & $3040 \pm 70$ & Vegetable fragments & $2912 \pm 26$ & 12003 \\
1161 & $5540 \pm 90$ & Charcoal & $5280 \pm 42$ & 12004 \\
1167 & $30,060 \pm 700$ & Peat & $29,875 \pm 261$ & 12005 \\
\hline
\end{tabular}

The second comparison performed was for a set of $5 \mathrm{CO}_{2}$ samples from lake sediment prepared at CENA and measured at UGAMS and LAC-UFF. Results are shown in Table 2. Once again, very good agreement was achieved for all the results. This set of samples was not measured at CENA due to the small sample quantities $(<1 \mathrm{~g} \mathrm{C})$, which were not enough for liquid scintillation counting.

Table $2 \mathrm{CO}_{2}$ from sediment samples produced at CENA and sent to UGAMS and LAC-UFF to be graphitized and measured.

\begin{tabular}{lccl}
\hline LAC-UFF \# & $\begin{array}{l}\text { LAC-UFF age } \\
\left({ }^{14} \mathrm{C} \text { yr BP) }\right.\end{array}$ & $\begin{array}{l}\text { CAIS (UGAMS) age } \\
\left({ }^{14} C \text { yr BP }\right)\end{array}$ & UGAMS \# \\
\hline 12006 & $884 \pm 34$ & $890 \pm 20$ & 11689 \\
12007 & $99.59 \pm 0.62^{\mathrm{a}}$ & $100.09 \pm 0.33^{\mathrm{a}}$ & 11687 \\
12008 & $1816 \pm 34$ & $1760 \pm 20$ & 11686 \\
12009 & $25,755 \pm 99$ & $26,110 \pm 70$ & 11691 \\
12010 & $25,579 \pm 98$ & $26,150 \pm 60$ & 11690 \\
\hline $\mathrm{a}_{\text {in }}$ pMC (percent of modern carbon). & &
\end{tabular}

The third comparison was a study of IAEA reference materials at LAC-UFF. Table 3 shows the results. Considering the error of $\pm 2 \sigma$ for all analyzed material, the data obtained for the IAEA C2, $\mathrm{C} 5$, and $\mathrm{C} 6$ samples are in agreement with the mean of results recorded by the intercomparison program involving 69 laboratories coordinated by the IAEA (Rozanski 1991). Table 3 also shows the values for the IAEA standards calculated at CENA and referenced to the oxalic acid SRM 4990C since 1992. All results are in agreement with the mean values of the international intercomparison program. The values for the UGAMS Laboratory are not presented because these standards are not being used for the regular measurements. The laboratory is using secondary standard materials 


\section{K D Macario}

NIST oxalic acid SRM 4990-C and wood FIRI (D, F). These standards have been measured routinely at the University of Georgia AMS facility since 2001. All calculations were referenced to NIST oxalic acid SRM 4990B as the primary standard (Cherkinsky et al. 2010).

Table 3 Percent of modern carbon (pMC) from IAEA reference materials.

\begin{tabular}{lcc}
\hline Sample & LAC-UFF / CENA-USP $(\mathrm{pMC})$ & Consensus value $(\mathrm{pMC})$ \\
\hline C2 & $40.49 \pm 0.41 / 41.09 \pm 0.40$ & $41.14 \pm 0.03$ \\
C5 & $22.89 \pm 0.08 / 22.75 \pm 0.30$ & $23.05 \pm 0.02$ \\
C6 & $149.20 \pm 0.66 / 149.80 \pm 0.79$ & $150.61 \pm 0.11$ \\
\hline
\end{tabular}

These results indicate that the AMS LAC-UFF presented very good analytical accuracy in this intercomparison exercise. It is therefore ready to begin routine analysis (despite improvements that will be made in its precision) and with research programs, mainly with Brazilian and Latin American groups in several areas of science, including geosciences, oceanography, and archaeology.

\section{CONCLUSIONS}

The new facility at the Universidade Federal Fluminense (LAC-UFF), Niteroi, Brazil, is the first ${ }^{14} \mathrm{C}$ AMS laboratory in Latin America. A 250kV single stage accelerator (SSAMS) system produced by NEC was installed and began operation in 2012. An intercomparison of results of 10 inorganic/ organic samples between the LAC-UFF and the conventional low-level liquid scintillation counting at CENA/USP and the AMS Laboratory (UGAMS) from the Center for Applied Isotopes Studies (CAIS), University of Georgia, USA, show very good agreement for all data sets. IAEA reference materials $\mathrm{C} 2, \mathrm{C} 5$, and $\mathrm{C} 6$ measured at LAC-UFF also showed agreement with the mean of results obtained for the analyzed materials. Efforts are underway to improve the background and precision of measurements in our SSAMS system.

\section{ACKNOWLEDGMENTS}

The authors would like to thank FINEP (Financiadora de Estudos e Projetos), CNPq (Conselho Nacional de Desenvolvimento Científico e Tecnológico,) CAPES (Coordenação de Aperfeiçoamento de Pessoal de Nível Superior), FAPESP (Fundação de Amparo à Pesquisa do Estado de São Paulo) (2007/03615-5 and 2011/00955-7), FAPERJ (Fundação de Amparo à Pesquisa do Estado do Rio de Janeiro), and the PRONEX (Programa de Apoio a Núcleos de Excelência) for financial support.

\section{REFERENCES}

Angulo RJ, Giannini PCF, Suguio K, Pessenda LCR. 1999. Relative sea-level changes in the last 5500 years in southern Brazil (Laguna-Imbituba region, Santa Catarina State) based on vermetid ${ }^{14} \mathrm{C}$ ages. Marine Geology 159:323-39.

Anjos RM, Macario KD, Lima TA, Veiga R, Carvalho C, Fernandes PJF, Vezzone M, Bastos J. 2010. Correlations between radiometric analysis of Quaternary deposits and the chronology of prehistoric settlements from the southeastern Brazilian coast. Journal of Environmental Radioactivity 101:75-81.

Anjos RM, Macario KD, Gomes PRS, Linares R, Queiroz E, Carvalho C. 2013. Towards a complete ${ }^{14} \mathrm{C}$ AMS facility at the Universidade Federal Fluminense
(Niterói, Brazil): sample preparation laboratory tests. Nuclear Instruments and Methods in Physics Research B 294:173-5.

Barbosa JA, Cordeiro RC, Silva EV, Turcq B, Santos GM, Gomes PRS, Sifeddine A, Albuquerque ALS, Lacerda LD, Hausladen PA, Tims SG, Fifield LK, Levchenko VA. 2004. ${ }^{14} \mathrm{C}$-AMS as a tool for the investigation of mercury deposition in a remote Amazon location. Nuclear Instruments and Methods in Physical Research B 223-224:528-34.

Barbosa M, Buarque A, Gaspar MD, Macario KD, Anjos RM, Gomes PRS, Coimbra MM, Elmore D. 2004. Intermittent occupation of the shellmound builder settlements at Rio de Janeiro State, Brazil. Nuclear Instru- 


\section{Brazilian AMS ${ }^{14} C$ Laboratory (LAC-UFF) and Intercomparison}

ments and Methods in Physics Research B 223-224: 695-9.

Buso Jr AA, Volkmer-Ribeiro C, Pessenda LCR, Machado VS. 2012. Anheteromeyetia vitrea (Porifera: Demospongiae): a new species of continental sponge at Brazil. Neotropical Biology and Conservation 7(3): $148-57$.

Cherkinsky A, Culp RA, Dvoracek DK, Noakes JE. 2010. Status of the AMS facility at the University of Georgia. Nuclear Instruments and Methods in Physics Research B 268(7-8):867-70.

Cohen MCL, Pessenda LCR, Behling H, Guimarães JTF, Rossetti DF, França MC, Smith CB. 2012. The Holocenic evolution of Northern Amazonian mangrove belt. Quaternary Science Reviews 55:50-8.

Cruz Jr FW, Burns SJ, Karmann I, Sharp WD, Vuille M. 2006. Reconstruction of regional atmospheric circulation features during the Late Pleistocene in subtropical Brazil from oxygen isotope composition of speleothems. Earth and Planetary Science Letters 248: 495-507.

Ferraz KC, Marques AN, Rodrigues EC, Santos GM, Gomes PRS. 2004. Use of ${ }^{14} \mathrm{C}$-AMS in the study of biological production in coastal upwelling areas. Brazilian Journal of Physics 34:732-6.

Freitas HA, Pessenda LCR, Aravena R, Gouveia SEM, Ribeiro AS, Boulet R. 2001. Late Quaternary vegetation dynamics in the Southern Amazon Basin inferred from carbon isotopes in soil organic matter. Quaternary Research 55:39-46.

Gomes PRS, Anjos RM, Santos GM, Acquadro JC, Macario KD, Liguori Neto R, Added N, Carlin Filho N, Medina NH, Cordeiro RC, Turcq BJ, Sifeddine A, Coimbra MM, Appoloni CR, Di Tada M, Cresswell RG, Fifield LK. 2000. Implementation of the AMS technique in Brazil and application on environmental studies in Amazon forest. Acta Physica Hungarica Heavy Ion Physics 11:485-96.

Gomes PRS, Santos GM, Ferraz KC, Marques AN, Barbosa JA, Cordeiro RC, Silva EV. 2004. Applications of ${ }^{14} \mathrm{C}$-AMS to environmental and economical problems. Nuclear Physics A 734:E116-E119.

Gouveia SEM, Pessenda LCR, Aravena R, Boulet R, Scheeel-Ybert R, Bendassoli JA, Ribeiro AS, Freitas HA. 2002. Carbon isotopes in charcoal and soils in studies of paleovegetation and climate changes during the Late Pleistocene and the Holocene in the southeast and centerwest regions of Brazil. Global and Planetary Change 33:95-106.

Guimarães JTF, Cohen MCL, Pessenda LCR, França MC, Smith CB, Nogueira ACR. 2012. Mid and Late Holocene sedimentary process and palaeeovegetation changes near the mouth of the Amazon River. The Holocene 22(3):359-70.

Ledru MP, Ceccantini G, Gouveia SEM, Lópes-Sáez JA, Pessenda LCR, Ribeiro AS. 2006. Millennial-scale climatic and vegetation changes in a northern Cerrado
(Northeast, Brazil) since the Last Glacial Maximum. Quaternary Science Reviews 25:1110-26.

Lima TA, Macario KD, Anjos RM, Gomes PRS, Coimbra MM, Elmore D. 2002. The antiquity of the prehistoric settlement of the central-south Brazilian coast. Radiocarbon 44(3): 733-8.

Lima TA, Macario KD, Anjos RM, Gomes PRS, Coimbra MM, Elmore D. 2003. The age of the early shellmound settlements of the southeast Brazilian coast. Brazilian Journal of Physics 33:276-9.

Lima TA, Macario KD, Anjos RM, Gomes PRS, Coimbra MM, Elmore D. 2004. The earliest shellmound settlements of the central-south Brazilian coast. $\mathrm{Nu}$ clear Instruments and Methods in Physical Research B 223-224:691-4.

Macario KD, Anjos RM, Gomes PRS, Figueiredo Jr AG, Souza CL, Barbosa CF, Coimbra MM, Elmore D. 2004. AMS radiocarbon dating on Campos Basin, southeast Brazilian Continental Slope. Nuclear Instruments and Methods in Physics Research B 223224:535-9.

Macario KD, Buarque A, Scheel-Ybert R, Anjos RM, Gomes PRS, Beauclair M, Hatté C. 2009. The long term Tupiguarani occupation in southeastern Brazil. Radiocarbon 51(3):937-46.

Pessenda LCR, Camargo PB. 1991. Datação radiocarbônica de amostras de interesse arqueológico e geológico por espectrometria de cintilação líquida de baixa radiação de fundo. Química Nova 14(2):98-103.

Pessenda LCR, Camargo PB, Cruz MVL, Lisi CS, Valencia EPE. 1993. O laboratório de radiocarbono do CENA/USP no programa internacional de intercomparação laboratorial de resultados. Química Nova 16(3):221-3.

Pessenda LCR, Boulet R, Aravena R, Rosolen V, Gouveia SEM, Ribeiro AS, Lamotte M. 2001. Origin and dynamics of soil organic matter and vegetation changes during the Holocene in a forest-savanna transition zone, Brazilian Amazon region. Holocene 11(2):250-4.

Pessenda LCR, Ribeiro AS, Gouveia SEM, Aravena R, Boulet R, Bendassoli. 2004a. Vegetation dynamics during the late Pleistocene in the Barreirinhas region, Maranhão State, northeastern Brazil, based on carbon isotopes in soil organic matter. Quaternary Research 62:183-93.

Pessenda LCR, Gouveia SEM, Aravena R, Boulet R, Valencia EPE. 2004b. Holocene fire and vegetation changes in southeastern Brazil as deduced from fossil charcoal and soil carbon isotopes. Quaternary International 114:35-43.

Pessenda LCR, Ledru MP, Gouveia SEM, Aravena R, Ribeiro AS, Bendassoli JA, Boulet R. 2005. Holocene palaeoenvironmental reconstruction in northeastern Brazil inferred from pollen, charcoal and carbon isotope records. The Holocene 15(6):814-22.

Pessenda LCR, De Oliveira PE, Mofatto M, Medeiros 


\section{KD Macario}

VB, Garcia RJF, Aravena R, Bendassolli JA, Leite AZ, Saad AR, Etchebehere ML. 2009. The evolution of a tropical rainforest/grassland mosaic in southeastern Brazil since $28,000{ }^{14} \mathrm{C}$ yr BP based on carbon isotopes and pollen records. Quaternary Research 71: 437-52.

Pessenda LCR, Gouveia SEM, Ribeiro AS, De Oliveira PE, Aravena R. 2010. Late Pleistocene and Holocene vegetation changes in northeastern Brazil determined from carbon isotopes and charcoal records in soils. Palaeogeography, Palaeoclimatology, Palaeoecology 297:597-608.

Pessenda LCR, Vidotto E, DE Oliveira PE, Buso Jr AA, Cohen MCL, Ricardi-Branco F. 2012. Late Quaternary vegetation and coastal environmental changes at Ilha do Cardoso mangrove record, southeastern Brazil. Palaeogeography, Palaeoclimatology, Palaeoecology 363-364:57-68.

Rossetti DF, Almeida S, Amaral DD, de Lima CM, Pessenda LCR 2010. Coexistence of Forest and savanna in an Amazonian area from a geological perspective. Journal of Vegetation Science 21:120-32.

Rozanski K. 1991. Consultants Group Meeting on C-14 Reference Materials for Radiocarbon Laboratories. Vienna: IAEA.

Saia SEMG, Pessenda LCR, Gouveia SEM, Aravena R,
Bendassolli JA. 2008. Last Glacial Maximum (LGM) vegetation changes in the Atlantic Forest, southeastern Brazil. Quaternary International 184:195-201.

Santos GM, Gomes PRS, Anjos RM, Cordeiro RC, Turcq B, Sifeddine A, Tada M, Cresswell R, Fifield LK. 2000. ${ }^{14} \mathrm{C}$ AMS dating of fires in the central Amazon rain forest. Nuclear Instruments and Methods in Physics Research B 172(1-4):761-5.

Santos GM, Cordeiro RC, Silva Filho EV, Gomes PRS, Lacerda LC, Sifeddine A, Turcq B. 2001. Chronology of atmospheric mercury deposition in the Amazon region, Brazil. Radiocarbon 43(2B):801-8.

Sifeddine A, Martin L, Turcq B, Volkmer-Ribeiro C, Soubies F, Cordeiro RC, Suguio K. 2001. Variations of the Amazon rainforest environment: a sedimentological record covering 30,000 years. Palaeogeography, Palaeoclimatology, Palaeoecology 168:221-35.

Stuiver M, Polach HA. 1977. Discussion: reporting of ${ }^{14} \mathrm{C}$ data. Radiocarbon 19(3):355-63.

Xu X, Trumbore SE, Zheng S, Southon JR, McDuffee KE, Luttgen M, Liu JC. 2007. Modifying a sealed tube zinc reduction method for preparation of AMS graphite targets: reducing background and attaining high precision. Nuclear Instruments and Methods in Physics Research B 259(1):320-9. 